\title{
ANALISIS DETERMINAN MINAT WIRAUSAHA PEMUDA DI KECAMATAN PERCUT SEI TUAN KABUPATEN DELI SERDANG
}

\author{
Ilham Mirzaya Putra \\ Sekolah Pascasarjana Universitas Sumatera Utara, Medan \\ Email: mnjm.ilham@gmail.com
}

\begin{abstract}
The objectives of this research were to determine: 1) the interest of young entrepreneurs in the district of Percut Sei Tuan, Deli Serdang Regency. 2) the influence of youth personalities, environment, and demography towards the interest of youth Entrepreneurship in the district of Percut Sei Tuan, Deli Serdang regency. Techniques used in the sampling was Franc Lynch. Research samples were taken from the youth in the district of Percut Sei Tuan aged from 18-30 years old, with 96 respondents obtained randomly. Data collection techniques used was primary, using questionnaires and a Likert scale on each question. The research method used was a survey. While for the data analysis technique a descriptive test and multiple linear regression were used. The result of this research revealed that: 1) Interest entrepreneurial youths in the district of Percut Sei Tuan in Deli Serdang area is very positive 2) Self efficacy, Achievement Needs, Availability Information, Networking, Access to Capital, and Demographics positively related to interest youth entrepreneurship in the district Percut Sei Tuan, Deli Serdang Regency. 3) Self efficacy, Achievement Needs, Availability Information, Networking, Access to Capital, and Demographics simultaneously significant effect on variable interest in youth entrepreneurship in the district Percut Sei Tuan, Deli Serdang Regency 4) Self efficacy, Achievement Needs, Availability Information, Networking, and Access to Capital partially no significant effect on variable interest in youth entrepreneurship in the district Percut Sei Tuan, Deli Serdang Regency. 5) Demographics partially have significant effect on variable of variable interest in youth entrepreneurship in the district Percut Sei Tuan, Deli Serdang Regency.
\end{abstract}

Key words: interest of entrepreneurs, young, personalities, environtment, demography

\section{PENDAHULUAN}

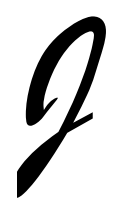

umlah penduduk Indonesia pada tahun 2015 sebanyak 255.615.4786 jiwa (Ditjen Kependudukan dan Catatan Sipil, Indonesia) . Mereka yang bertempat tinggal di daerah perkotaan sebanyak $56 \%$ dan di daerah perdesaan sebanyak $46 \%$. Angka tersebut sekaligus menempatkan Indonesia sebagai negara

QE Journal | Vol.06 - No. 01 Maret 2017 - 48 
berpenduduk terbesar nomor empat di dunia. Pertumbuhan penduduk yang terus bertambah setiap tahunnya akan menambah jumlah tenaga kerja sehingga jumlah lapangan pekerjaan yang disediakan harus terus ditingkatkan.

Deli serdang, merupakan salah satu kabupaten di Sumatera Utara. Ibukota Deli Serdang, Lupuk Pakam, memiliki jarak terdekat kedua dengan kota Medan, yang hanya berjarak $29 \mathrm{~km}$, setelah kota Binjai. Selain itu, Deli serdang memiliki jumlah penduduk terbanyak setelah Medan, yaitu 1.984.598 jiwa. Dengan jumlah penduduk yang terbilang besar tersebut, Deli Serdang mampu menjadi kabupaten dengan persentase penduduk miskin terkecil yaitu hanya 4,71\%. Ditinjau dari segi Indeks Pembangunan Manusia (IPM), Deli serdang merupakan IPM kabupaten terbesar kedua setelah toba samosir sebesar 71,98. Bahkan, IPM-nya melebihi kota Sibolga dan Gunung sitoli. Namun, Deli Serdang menempati urutan kedua jumlah pengangguran angkatan kerja setelah Medan, yaitu sebesar 62.871 jiwa. Deli serdang juga merupakan kabupaten dengan pencari pekerja terbesar yaitu 31.754 jiwa.

Bedasarkan Rencana Tata Ruang (RTR) kawasan Mebidangro, ditetapkan sembilan kecamatan yang menjadi Pusat Pelayanan Kawasan (PPK) di Kabupaten Deli Serdang diantaranya adalah Kecamatan Percut Sei Tuan. Khusus di Kecamatan Percut Sei Tuan, dalam rencana system perkotaan Kabupaten Deli Serdang tahun 2025, fungsi yang dikembangkan ada lima hal, yaitu Perdagangan dan jasa regional; Pengolahan pertanian dan perikanan; Perumahan dan permukiman: Industri; Pusat pendidikan dan olah raga.

Isu Strategis Pembangunan berasal dari permasalahan pembangunan dan analisis lingkungan eksternal. Analisis lingkungan eksternal diambil dari berbagai informasi dari dunia Internasional, Kebijakan Nasional, dan Regional Sumatera Utara. Isu Strategis Pembangunan yang tertuang dalam Rencana Pembangunan Jangka Menengah (RPJM) Kabupaten Deli Serdang menempatkan Kecamatan Percut Sei Tuan menjadi salah satu konsentrasi utama pengembangan kawasan Industri.

Kewirausahaan (entrepreneurship) sangat dibutuhkan bangsa Indonesia. Kewirausahaan bukan hanya semata-mata berperan sebagai alternative untuk menekan jumlah pengangguran, namun juga sebagai pendorong 
perubahan sosial bagi peningkatan kualitas hidup manusia. Menurut Siswoyo (2009) pentingnya peranan kewirausahaan dapat dilihat dari kenyataan bahwa pada tahun 1980-an di Amerika telah lahir sebanyak 20 juta wirausaha baru yang menciptakan banyak sekali lapangan pekerjaan baru. Shastri (2009) menyatakan bahwa setiap wirausaha yang sukses memberikan manfaat tidak hanya bagi dirinya sendiri tetapi juga memberikan manfaat kepada komunitas, daerah dan negaranya.

Berdasarkan Rencana Jangka Menengah Daerah (RJMD) Kabupaten Deli Serdang, kewirausahaan menjadi salah satu konsentrasi pembangunan. Kewirausahaan menjadi tanggungjawab dua instansi sekaligus, yaitu Dinas Pemuda dan Olahraga (Dispora) dan Dinas Koperasi dan Usaha Kecil Menengah (UKM).

Dalam mencapai tujuan dan sasaran pembangunan, maka disusunlah strategi pembangunan Kabupaten Deli Serdang dalam mewujudkan visi dan misi kedaerahan dalam jangka waktu lima tahun kedepan, antara lain adalah Meningkatkan Sumber Daya Manusia yang berkualitas dan Membangun perekomomian yang kokoh dan berkeadilan. Dalam hal meningkatkan kualitas Sumber Daya Manusia, masyarakat Deli Serdang didorong untuk memiliki keterampilan wirausaha. Sementara itu, dalam hal pembangunan perekonomian, pemerintah mendorong aktivitas masyarakat dalam berwirausaha melalui pemberian fasilitas.

Masyarakat harus memiliki minat yang tinggi terhadap pembukaan unit usaha yang baru. Terlebih lagi masyarakat yang berada pada usia produktif yaitu pemuda. Karena pemuda memiliki karakteristik khas yang dibutuhkan untuk menjadi seorang wirausaha. Inti tujuan pembangunan kepemudaan menurut UU No. 40/2009 menekankan pada tiga hal yaitu karakter, kapasitas, dan daya saing. Berjiwa kepemimpinan, kewirausahaan, kepeloporan, dan kebangsaan adalah salah satu tujuan pembangunan kepemudaan yang mencakup karakter dan kapasitas sekaligus. Oleh karena itu, tidak heran mengapa pemuda dan minat kewirausahaan menjadi objek penelitian yang menarik untuk diteliti.

Minat merupakan faktor pendorong yang menjadikan seseorang lebih giat bekerja dan memanfaatkan setiap peluang yang ada dengan mengoptimalkan potensi yang tersedia. Minat tidak muncul begitu saja tetapi tumbuh dan berkembang sesuai dengan faktor-faktor yang 
mempengaruhinya (Walgito, 2003:148). Minat berwirausaha dipengaruhi oleh beberapa factor, diduga yang mendeterminasi diantaranya adalah karakteristik kepribadian, faktor demografi dan karakteristik lingkungan. Karakteristik kepribadian seperti efikasi diri dan kebutuhan akan prestasi merupakan prediktor yang signifikan berpengaruh terhadap minat berwirausaha. Faktor demografi seperti umur, jenis kelamin, latar belakang pendidikan dan pengalaman bekerja seseorang diperhitungkan sebagai penentu bagi minat berwirausaha. Faktor lingkungan seperti hubungan sosial, infrastruktur fisik dan institusional serta faktor budaya dapat mempengaruhi minat berwirausaha (Indarti, 2008).

Efikasi diri adalah kepercayaan seseorang atas kemampuan dirinya untuk menyelesaikan suatu pekerjaan. Efikasi diri akan karir seseorang adalah domain yang menggambarkan pribadi seseorang dalam hubungannya dengan proses pemilihan dan penyesuaian karir (Betz dan Hacket, 2006). Oleh karena itu, efikasi diri akan karir seseorang dapat menjadi faktor penting dalam tahapan awal seseorang memulai karirnya. Lebih lanjut, Betz dan Hacket menyatakan bahwa semakin tinggi tingkat efikasi diri seseorang pada kewirausahaan di masa-masa awal seseorang dalam berkarir, semakin kuat minat kewirausahaan yang dimilikinya. Lebih lanjut, Bandura (2006) menjelaskan bahwa ada empat cara mencapai efikasi diri, yaitu; pengalaman sukses yang terjadi berulang-ulang, pembelajaran melalui pengamatan langsung, persuasi sosial, dan penilaian terhadap status psikologis yang dimiliki.

Kebutuhan akan prestasi dapat diartikan sebagai suatu kesatuan watak yang memotivasi seseorang untuk menghadapi tantangan untuk mencapai kesuksesan dan keunggulan. Kebutuhan akan prestasi juga dapat mendorong kemampuan pengambilan keputusan dan kecenderungan untuk mengambil resiko seorang wirausaha (Indarti, 2008). Meskipun demikian, Scapinello (dalam Indarti, 2008) menyatakan bahwa seseorang dengan tingkat kebutuhan akan prestasi yang tinggi kurang dapat menerima kegagalan daripada mereka dengan kebutuhan akan prestasi rendah.

Wirausahawan harus dapat menentukan jumlah modal yang diperlukan guna memulai sebuah usaha. Seorang wirausaha pertama-tama harus menentukan jumlah minimum dari masing-masing sumber daya yang diperlukan. Kesulitan dalam mendapatkan akses modal, skema kredit dan

QE Journal | Vol.06 - No. 01 Maret 2017 - 51 
kendala sistem keuangan dipandang sebagai hambatan utama dalam kesuksesan wirausaha di negara-negara berkembang. Penelitian relatif baru menyebutkan bahwa akses kepada modal menjadi salah satu penentu kesuksesan suatu usaha (Kristiansen et al, 2003).

Ketersediaan informasi usaha merupakan faktor penting yang mendorong keinginan seseorang untuk membuka usaha baru dan faktor kritikal bagi pertumbuhan dan keberlangsungan usaha (Indarti, 2008). Pencarian informasi mengacu pada frekuensi komunikasi yang dibuat oleh seseorang dengan berbagai sumber informasi. Hasil dari aktivitas tersebut adalah ketersediaan informasi, baik melalui usaha sendiri atau sebagai bagian dari sumber daya sosial dan jaringan. Ketersediaan informasi akan tergantung pada karakteristik seseorang, seperti tingkat pendidikan dan kualitas infrastruktur, meliputi cakupan media dan sistem telekomunikasi (Kristiansen, 2002).

Jaringan sosial didefinisikan sebagai hubungan antara dua orang yang mencakup a) komunikasi atau penyampaian informasi dari satu pihak ke pihak lain; b) pertukaran barang dan jasa dari dua belah pihak; dan c) muatan normatif atau ekspektasi yang dimiliki oleh seseorang terhadap orang lain karena karakter-karakter atau atribut khusus yang ada. Bagi wirausaha, jaringan merupakan alat mengurangi resiko dan biaya transaksi serta memperbaiki akses terhadap ide-ide bisnis, informasi dan modal, (Aldrich dan Zimmer, dalam Indarti, 2008).

Hal senada diungkap oleh Kristiansen (2003) yang menjelaskan bahwa jaringan sosial terdiri dari hubungan formal dan informal antara pelaku utama dan pendukung dalam satu lingkaran terkait dan menggambarkan jalur bagi wirausaha untuk mendapatkan akses kepada sumber daya yang diperlukan dalam pendirian, perkembangan dan kesuksesan usaha.

Riyanti (2003), menyatakan bahwa demografi sangat penting dikaji karena demografi adalah faktor yang melekat pada wirausaha dan mempengaruhi keberhasilan seorang wirausaha. Mazzarol dalam Indarti et al (2008) menyatakan bahwa faktor-faktor demografi seperti jender, umur, pendidikan dan pengalaman bekerja seseorang berpengaruh terhadap keinginan seseorang untuk menjadi seorang wirausaha.

Indarti et al (2008) meneliti minat kewirausahaan mahasiswa Indonesia, Jepang dan Norwegia selama 2002 - 2006 dengan judul "Intensi 
Kewirausahaan Mahasiswa: Studi Perbandingan Antara Indonesia, Jepang dan Norwegia. Metode analisis data menggunakan analisis regresi berganda. Dari hasil penelitian Indarti et al (2008) diperoleh kesimpulan bahwa 1) kebutuhan akan prestasi tidak berpengaruh terhadap minat kewirausahaan mahasiswa pada mahasiswa ketiga Negara, 2) efikasi diri mempengaruhi minat kewirausahaan mahasiswa Indonesia dan Norwegia tetapi tidak mempunyai pengaruh pada mahasiswa Jepang, 3) kesiapan instrumen atau lingkungan hanya mempengaruhi minat kewirausahaan mahasiswa Norwegia dan tidak mempengaruhi pengaruh terhadap minat kewirausahaan mahasiswa Indonesia dan Jepang, 4) jender dan usia yang lebih muda tidak mempunyai pengaruh terhadap minat kewirausahaan mahasiswa ketiga negara, 5) latar belakang pendidikan ekonomi dan bisnis tidak mempunyai pengaruh terhadap minat kewirausahaan mahasiswa Indonesia dan Jepang, sebaliknya minat kewirausahaan pada mahasiswa Indonesia dengan latar belakang pendidikan bisnis dan ekonomi malah lebih rendah, 6) pengalaman kerja mempengaruhi minat kewirausahaan pada mahasiswa Norwegia, tetapi tidak mempunyai pengaruh terhadap mahasiswa Indonesia dan Jepang.

Setiyorini (2009) meneliti minat berwirausaha mahasiswa Universitas Sebelas Maret Surakarta dengan judul "Pengaruh Faktor Personal dan Lingkungan terhadap Keinginan Berwirausaha" dengan jumlah responden 100 orang. Dari hasil penelitian Setiyorini ini didapat kesimpulan bahwa 1) efikasi diri mahasiswa Universitas Sebelas Maret Surakarta adalah moderat, 2) mahasiswa memiliki motivasi berprestasi yang tinggi dan locus of control yang moderat, 3) akses terhadap modal yang rendah 4) kemampuan mengakses informasi yang moderat dan 5) kepemilikan hubungan sosial yang moderat. Dari uji $\mathrm{R}^{2}$ diperoleh kesimpulan bahwa faktor personal dan lingkungan dapat menjelaskan minat kewirausahaan mahasiswa Universitas Sebelas Maret sebesar 44\%, sisanya sebesar 56\% dijelaskan oleh faktor lain yang tidak diteliti. Secara umum minat kewirausahaan mahasiswa Universitas Sebelas Maret Surakarta yang diteliti adalah moderat

Hermin et al (2013) meneliti minat berwirausaha mahasiswa Universitas Muhammadiyah Ponorogo (UMP) dan Universitas Soedirman (UnSoed) dengan judul "Intensi Kewirausahaan Mahasiswa (Studi Perbandingan antara mahasiswa FE UMP dan FE UnSoed)" dengan jumlah responden 
214 mahasiswa (UMP; 102, Unsoed; 112). Penelian Hermin et al, memperoleh kesimpulan, 1) Inovasi mempengaruhi intensi kewirausahaan mahasiswa 2) Kepercayaan diri mempengaruhi intensi kewirausahaan mahasiswa, 3) Secara parsial kesiapan instrument (akses modal, kepemilikan jaringan, akses informasi) tidak mempengaruhi intensi kewirausahaan mahasiswa, 4) Secara parsial, efikasi diri tidak mempengaruhi intensi kewirausahaan mahasiswa, 5) Tidak ada hubungan profesi orangtua hubungan profesi orangtua terhadap intensi kewirausahaan mahasiswa, 6) Ada hubungan prestasi akademik terhadap intensi kewirausahaan mahasiswa, 7) Tidak ada huhubungan pengalaman bekerja terhadap intensi kewirausahaan, 8) Tidak ada perbedaan intensi kewirausahaan di FE UMP dan FE UnSoed.

\section{METODE PENELITIAN}

Penelitian ini menganalisis determinan minat wirausaha pemuda di kecamatan Percut Sei Tuan. Determinan yang digunakan dalam penelitian ini yaitu Kebutuhan Prestasi, Efikasi Diri, Ketersediaan Informasi, Jaringan, Akses Modal, dan Demografi. Periode penelitian adalah bulan Juni Agustus 2016. Daerah penelitian dipilih secara sengaja (purposive) dengan mempertimbangkan bahwa Kecamatan Percut Sei tuan, menjadi kecamatan satu-satunya di Kabupaten Deli Serdang yang masuk dalam kawasan rencana pembangunan kawasan cepat tumbuh, kawasan ekonomi terpadu dan kota Mandiri

Berbeda dari mayoritas penelitian sejenis yang menjadikan mahasiswa sebagai objek penelitian, penelitian ini menjadikan pemuda sebagai objek penelitian. Sehingga objek penelitian lebih heterogen. Populasi penelitian ini adalah seluruh pemuda yang berdomisili di Kacamatan Percut Sei Tuan. Perhitungan sampel menggunakan rumus perhitungan Frank Lynch (Irawan, 2006):

$$
\mathrm{n}=\frac{\mathrm{Nz} z^{2} \cdot \mathrm{p}(1-\mathrm{p})}{\mathrm{N} d^{2}+z^{2} \cdot \mathrm{p}(1-\mathrm{p})}
$$

Menurut Badan Pusat Statistik tahun 2016, jumlah penduduk menurut kelompok umur 15-29 tahun berjumlah 121.456 jiwa atau 26 persen dari jumlah penduduk Kecamatan Percut Sei Tuan. Berdasarkan rumus frank Lynch maka ditetapkan sampel penelitian sebanyak 96 orang. 
Berdasarkan jenis masalah yang diteliti, teknik yang digunakan pada penelitian ini adalah deskriptif kuantitatif. Adapun sifat penelitian adalah penelitian penjelasan (explanotary research) yang berkaitan dengan kedudukan variabel-variabel yang diteliti serta pengaruh antara satu variabel dengan variabel yang lain.

Sumber data penelitian ini diperoleh secara langsung dari sumbernya yaitu melalui daftar pertanyaan dan wawancara dengan tujuan agar mendapat tingkat pengembalian yang tinggi dan akurat. Pengumpulan data dilakukan di sekitar aktivitas pemuda; di warung, rumah, sekolah, rumah ibadah, pasar, dan lapangan olahraga. Teknik ini digunakan agar peneliti dapat memperoleh responden dari latar belakang demografi yang berbedabeda Selain itu, adapula data sekunder yang diperoleh dari studi dokumentasi berupa dokumen-dokumen resmi yang diterbitkan oleh Badan Pusat Statistik, Direktorat Jenderal Kependudukan dan Catatan Sipil, dan Kantor Camat Percut Sei Tuan.

Metode analisis data yang digunakan dalam penelitian ini adalah uji deskriptif dengan melihat skor rata-rata dan analisis regresi berganda. Uji deskriptif memaparkan data dan angka yang diperoleh dari pengamatan di lapangan, kemudian disajikan dalam bentuk tabel (Arikunto, 2002).

Analisis regresi digunakan untuk mengetahui arah hubungan antara variabel bebas dengan variabel terikat apakah masing-masing variabel bebas berhubungan positif atau negatif dan untuk memprediksi nilai dari variabel terikat apabila nilai variabel bebas mengalami kenaikan atau penurunan. Model regresi linier berganda, sebagai berikut:

$$
Y=\alpha+\beta_{1} X_{1}+\beta_{2} X_{2}+\beta_{3} X_{3}+\beta_{4} X_{4}+\beta_{5} X_{5}+\beta_{6} X_{6}+\varepsilon
$$

Pengaruh variabel bebas terhadap variabel terikat diuji dengan tingkat kepercayaan (convidence interval) $95 \%$ atau $\alpha=0,05$. Uji hipotesis dengan menggunakan uji simultan (Uji F), dan uji parsial (Uji t). Variabel bebas dalam penelitian ini adalah Kebutuhan Prestasi $\left(\mathrm{x}_{1}\right)$, Efikasi Diri $\left(\mathrm{x}_{2}\right)$, Ketersediaan Informasi ( $\left.\mathrm{x}_{3}\right)$, Jaringan ( $\left.\mathrm{x}_{4}\right)$, Akses Modal ( $\left.\mathrm{x}_{5}\right)$, dan Demografi (x6). Sedangkan variable terikatnya adalah minat wirausaha pemuda.(Y)

\section{HASIL DAN PEMBAHASAN}

Responden dalam penelitian ini berjumlah 96 orang dengan komposisi masing-masing laki-laki dan perempuan sebanyak 48 orang. Berdasarkan 
suku, responden terbanyak adalah suku Jawa sebanyak 42 orang, disusul kemudian berturut-turut suku Batak, Melayu, Aceh, Padang, dan Sunda. Berdasarkan tingkat pendidikan, responden didominasi oleh tingkat pendidikan Strata-1 dan Sekolah Menengah Atas (SMA). Berdasarkan jenis pekerjaan, Guru menjadi mayoritas dengan jumlah 32 orang, disusul Wirausaha dan Mahasiswa. Sementara itu untuk jumlah penghasilan, mayoritas responden memiliki penghasilan sebesar $R p 1.000 .000 \leq x \leq R p$ 2.000.000 sebanyak 41 orang, sementara itu untuk penghasilan dibawah Rp. 1 juta sebesar 39 orang. Hampir seluruh responden belum memiliki tanggungan, sebanyak 74 orang belum memiliki tanggungan, dan hanya 14 orang yang memiliki tanggungan 1 orang.

Uji validitas dilakukan dengan membandingkan nilai correlated item - total correlation pada setiap butir pertanyaan terhadap nilai $r$ variabel. Sunyoto (2009) menyatakan jika nilai correlated item - total correlation rhitung > nilai rtabel dan nilainya positif, maka butir pertanyaan pada setiap variabel penelitian dinyatakan valid. Nilai rabel pada $\mathrm{df}=\mathrm{n}-2=96-2=94$ dan $\alpha=0,05$ adalah 0,168 . Tidak ada satupun nilai correlated item - total correlation di bawah 0,168, maka seluruh butir pertanyaan valid.

Sunyoto (2009) menyatakan bahwa butir pertanyaan disebut reliabel atau handal jika jawaban seseorang terhadap pertanyaan bersifat konsisten dari waktu ke waktu. Pengukuran reliabilitasnya menggunakan uji statistik Cronbach Alpha. Menurut Sunyoto (2009: 68) suatu konstruk dikatakan reliabel jika memberikan nilai Cronbach Alpha $>0,60$. Seluruh Cronbach Alpha di setiap butir pertanyaan bernilai di atas 0,60 , maka seluruh butir pertanyaan reliable.

Uji normalitas adalah untuk menguji apakah data dalam sebuah model berdistribusi normal atau tidak. Jika data tidak berdistribusi normal, maka hasil analisis akan menjadi bias (Suntoyo, 2009). Uji normalitas dapat dilakukan dengan cara membuat normal probability plot yang membandingkan data riil dengan data distribusi normal secara kumulatif. Suatu data dikatakan mempunyai distribusi normal jika garis riil mengikuti garis diagonal. 


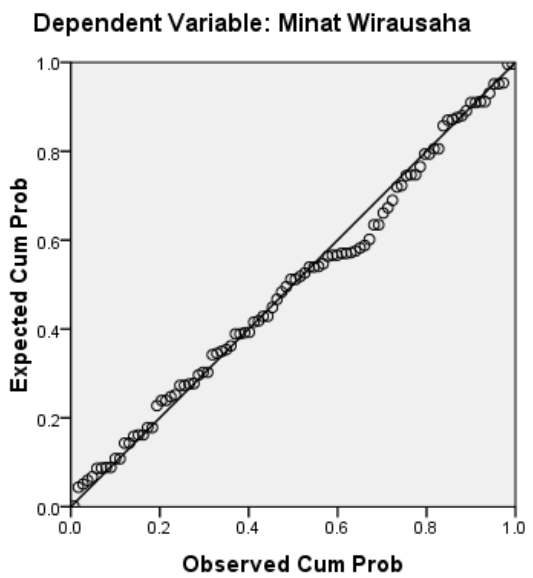

Gambar 1. Hasil uji Normalitas

Uji multikolinearitas dipakai untuk mengukur tingkat asosiasi/keeratan hubungan/pengaruh antarvariabel bebas/variabel bebas. Sunyoto (2009) lebih lanjut menyatakan bahwa untuk mendeteksi adanya multikolinearitas dapat dilihat dari nilai tolerance dan variance inflation factor (VIF), jika nilai tolerance $<0,10$ dan nilai VIF $>10$ maka terjadi multikolinearitas dan sebaliknya jika nilai tolerance $>0,10$ dan nilai $\mathrm{VIF}<10$, maka dikatakan tidak terjadi multikolinearitas.

Tabel 1. Hasil Uji Multikolinearitas

\begin{tabular}{llll}
\hline \multicolumn{1}{c}{ Model } & \multicolumn{2}{c}{ Collinearity Statistics } \\
& \multicolumn{2}{c}{ Tolerance } & VIF \\
\hline 1 & (Constant) & 1.567 \\
Kebutuhan Prestasi & .638 & 1.674 \\
Efikasi Diri & .597 & 2.475 \\
Ketersediaan Informasi & .404 & 3.002 \\
& Jaringan & .333 & 3.106 \\
& .322 & 2.482 \\
\hline
\end{tabular}

Sumber: Hasil Pengolahan Data

QE Journal | Vol.06 - No. 01 Maret 2017 - 57 
Sunyoto (2009) menyatakan bahwa uji heteroskedastisitas dipakai untuk menguji sama atau tidaknya varians dari residual observasi yang satu dengan observasi yang lain. Dikatakan tidak terjadi homoskedastisitas jika pada grafik scatterplot titik-titik hasil pengolahan data antara ZPRED dan SRESID menyebar di bawah atau di atas titik nol pada sumbu $Y$ dan tidak mempunyai pola yang teratur. Sebaliknya jika titik-titik tersebut mempunyai pola yang teratur, baik menyempit, melebar maupun bergelombang maka dikatakan terjadi heteroskedastisitas. Model yang baik adalah model yang tidak mengalami heteroskedastisitas.

Scatterplot

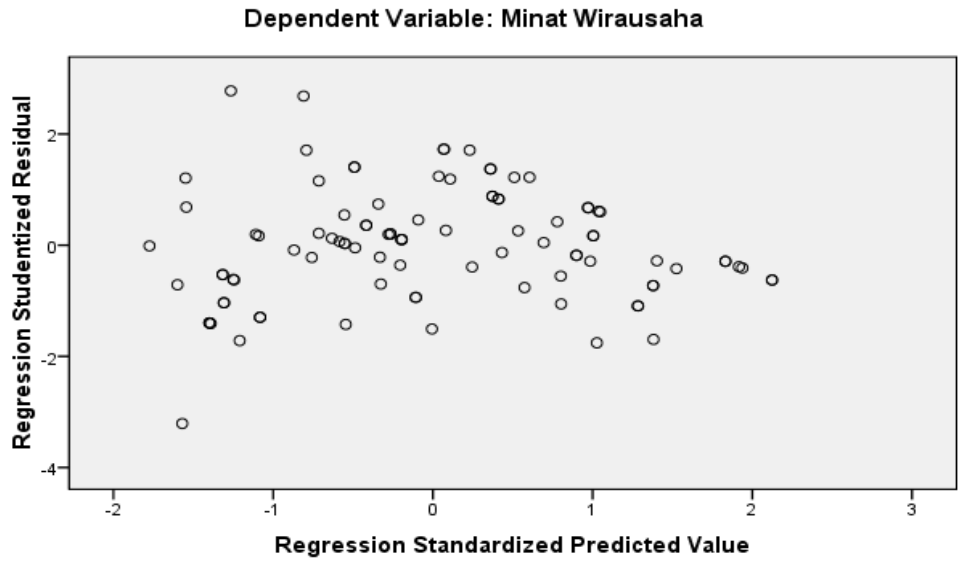

Gambar 2. Hasil Uji Heteroskedastisitas

Berdasarkan uji asumsi klasik yang telah dilakuakan, dapat disimpulkan bahwa uji normalitas, multikolinieritas, dan heteroskedastisitas menunjukkan hasil yang baik dan layak untuk dianalisis lebih lanjut.

Data analisis dikemukakan untuk mengetahui mean (rata-rata) kemudian ditarik kesimpulan berdasarkan angka yang diperoleh. Nilai rata-rata pada variabel terikat adalah 4,06 hal ini berarti minat wirausaha pemuda di Kecamatan Percut Sei Tuan berada pada daerah sangat positif.

Hasil Uji deskriptif Jenis Kelamin terhadap minat wirausaha menjelaskan bahwa Minat wirausaha pemuda laki-laki berada pada daerah sangat positif $(4,29)$, sedangkan perempuan berada pada daerah positif $(3,83)$. Dengan demikian, minat berwirausaha laki-laki lebih tinggi daripada 
perempuan pada pemuda di Kecamatan Percut Sei Tuan. Temuan penelitian ini mendukung hasil penelitian Azhar et al (2010), yang menyatakan bahwa jenis kelamin berkorelasi positif dengan minat berwirausaha. Indarti dan Rostiani (2008:10) mengungkapkan bahwa mahasiswa laki-laki memiliki intensi yang lebih kuat dibandingkan mahasiswa perempuan untuk berwirausaha

Hasil Uji deskriptif menjelaskan bahwa Minat wirausaha pemuda suku Jawa berada pada daerah sangat positif $(4,32)$, sedangkan Batak $(3,67)$ dan Melayu $(3,98)$ berada pada daerah positif. Dengan demikian, minat berwirausaha suku Jawa adalah yang paling tinggi diikuti Melayu dan Batak secara. Hasil penelitian ini mendukung penelitian Wiwik et al (2011), yang menemukan bahwa suku Jawa memiliki minat wirausaha lebih tinggi dibandingkan suku Batak.

Hasil uji deskriptif menjelaskan bahwa minat wirausaha pemuda dengan tingkat pendidikan SMA dan S-1, kedua-duanya berada pada daerah sangat positif. Meskipun demikian, minat wirausaha pemuda lulusan SMA $(4,11)$ lebih tinggi dibanding lulusan S-1 di Kecamatan Percut Sei Tuan. Hasil penelitian ini sesuai dengan Masrun dalam Yuwono et al (2004), menyatakan bahwa banyak lulusan perguruan tinggi belum mampu berwirausaha. Mahasiswa cenderung berpikir bagaimana caranya mereka bisa diterima bekerja sesuai dengan gelar kesarjanaannya dan dengan gaji yang sesuai ketika menyelesaikan kuliahnya. Lebih lanjut Masrun menyatakan bahwa penduduk yang mempunyai pendidikan tinggi justru kurang berminat menjadi wirausaha, tercatat hanya $10 \%$ yang berminat menjadi wirausaha. Mereka yang pendidikannya rendah justru 49\% yang berminat menjadi wirausaha.

Hasil uji deskriptif menjelaskan bahwa minat wirausaha pemuda para wirausahawan $(4,19)$ dan mahasiswa $(4,03)$ berada pada daerah sangat positif, sementara guru berada pada daerah positif $(3,97)$ di Kecamatan Percut Sei Tuan. Lebih lanjut, hasil penelitian menunjukkan minat wirausaha para wirausahawan lebih tinggi dibandingkan mahasiswa dan guru secara berurutan. Hasil penelitian ini mendukung penelitian Tisnawari (2012) yang menyatakan bahwa pengalaman kewirausahaan berpengaruh positif terhadap minat kewirausahaan. Lebih lanjut, Minniti dan Bygrave (2001) mengatakan bahwa pengalaman berwirausaha, berhasil

QE Journal | Vol.06 - No. 01 Maret 2017 - 59 
maupun tidak, menyediakan peluang untuk menguasai sejumlah keahlian dan untuk berhubungan dengan stakeholder dari wirausahawan lain.

Hasil uji deskriptif menjelaskan bahwa minat wirausaha pemuda berpenghasilan kurang dari Rp. 1.000 .000 dan antara Rp.1.000.000 hingga Rp.2.000.000 berada pada daerah positif, sementara itu pemuda yang berpenghasilan antara Rp 2.000.000 hingga Rp 3.000.000 berada pada daerah sangat positif. Hasil penelitian menunjukkan bahwa ada hubungan positif antara jumlah penghasilan dan minat wirausaha pemuda di Kecamatan Percut Sei Tuan. Lebih lanjut, penelitian suhartini (2011) menyimpulkan bahwa pendapatan berpengaruh terhadap minat wirausaha. Seseorang tertarik untuk menjadi wirausaha dikarenakan ekspektasi pendapatan yang diperolehnya jika sukses melebihi pendapatannya dalam kondisi eksisting.

Hasil uji deskriptif menjelaskan bahwa minat wirausaha pemuda yang memiliki tanggungan satu orang berada pada daerah sangat positif yaitu 4.12 dan yang belum memiliki tanggungan berada pada daerah positif; 4.01. Jumlah tanggungan keluarga akan menentukan minat pemuda di Kecamatan Percut Sei Tuan untuk melakukan wirausaha. Semakin banyak tanggungan dalam keluarga turut mempengaruhi kebutuhan konsumsi dan pendapatan. Berwirausaha akan memberikan peluang untuk meningkatkan pendapatannya.

Pengaruh variabel bebas terhadap variabel terikat diuji dengan membandingkan Fhitung dan Ftabel pada tingkat kepercayaan (confidence interval) $95 \%$ atau $\alpha=5 \%$. Fhitung dapat dilihat pada Tabel 2 .

Tabel 2. Hasil Uji Simultan (Uji-F)

\begin{tabular}{|c|c|c|c|c|c|c|}
\hline \multicolumn{7}{|c|}{ ANOVA $^{b}$} \\
\hline Model & & Sum of Squares & $\mathrm{df}$ & Mean Square & $\mathrm{F}$ & Sig. \\
\hline \multirow[t]{3}{*}{1} & Regression & 33.642 & 6 & 5.607 & 19.205 & $.000^{\mathrm{a}}$ \\
\hline & Residual & 25.983 & 89 & .292 & & \\
\hline & Total & 59.625 & 95 & & & \\
\hline
\end{tabular}

Sumber: Hasil Pengolahan Data

Berdasarkan Tabel 2, dapat diketahui bahwa variabel Efikasi Diri, Kebutuhan Prestasi, Ketersediaan Informasi, Jaringan, Akses Modal, dan Demografi secara simultan berpengaruh signifikan terhadap variabel minat 
kewirausahaan pemuda di Kecamatan Percut Sei Tuan. Fhitung sebesar 19,205 sedangkan Ftabel sebesar 2,20. maka Fhitung > Ftabel. Dan signifikansi lebih kecil dari 0,05.

Pengolahan data tersebut menghasilkan suatu model regresi linear berganda sebagai berikut:

$$
Y=0,254+0,127 X_{1}+0,170 X_{2}+0.204 X_{3}+0,134 X_{4}+0,091 X_{5}+0,289 X_{6}+e
$$

Tabel 3. Hasil Estimasi Regresi

\begin{tabular}{|c|c|c|c|c|}
\hline \multirow{2}{*}{\multicolumn{2}{|c|}{ Model }} & \multicolumn{2}{|c|}{ Unstandardized Coefficients } & \multirow{2}{*}{$\begin{array}{l}\text { Standardized } \\
\text { Coefficients } \\
\text { Beta }\end{array}$} \\
\hline & & B & Std. Error & \\
\hline \multirow[t]{7}{*}{1} & (Constant) & .254 & .500 & \\
\hline & Kebutuhan Prestasi & .127 & .132 & .084 \\
\hline & Efikasi Diri & .170 & .128 & .120 \\
\hline & Ketersediaan Informasi & .204 & .109 & .205 \\
\hline & Jaringan & .134 & .146 & .111 \\
\hline & Akses Modal & .091 & .108 & .104 \\
\hline & Demografi & .289 & .106 & .302 \\
\hline
\end{tabular}

Sumber: Hasil Pengolahan Data

Hasil regresi linier berganda memberikan kesimpulan bahwa kebutuhan prestasi, efikasi diri, ketersediaan informasi, kepemilikan jaringan, dan akses modal memiliki hubungan positif terhadap minat wirausaha. Sementara jika seluruh varibel bebas tidak ada atau nol, maka minat wirausaha tetap ada meskipun kecil sebesar 0,254.

Tabel 4. Hasil Koefisien Determinasi

\begin{tabular}{llllll}
\hline Model & $\mathrm{R}$ & R Square & $\begin{array}{l}\text { Adjusted } \\
\text { Square }\end{array}$ & $\begin{array}{l}\text { R Std. Error of the Durbin-Watson } \\
\text { Estimate }\end{array}$ \\
\hline 1 & $.751^{\mathrm{a}}$ & .564 & .535 & .54032 & 1.662 \\
\hline
\end{tabular}

Sumber: Hasil Pengolahan Data

Berdasarkan Tabel 5 diperoleh $\mathrm{R}$ square (R2) sebesar 0,564 yang artinya variabel Efikasi Diri, Kebutuhan Prestasi, Ketersediaan Informasi, Jaringan, Akses Modal, dan Demografi secara serempak mampu menjelaskan variabel minat kewirausahaan sebesar $56,4 \%$. Sisanya $43,6 \%$ dipengaruhi oleh faktor lain yang tidak diteliti.

QE Journal | Vol.06 - No. 01 Maret 2017 - 61 
Faktor lain yang belum diteliti cukup banyak antara lain penelitian Basu (2009) menemukan bahwa faktor etnisitas dan pekerjaan mempengaruhi minat kewirausahaan. Kebijakan dan peraturan pemerintah juga merupakan faktor yang mempengaruhi pertumbuhan jiwa kewirausahaan. Penelitian oleh Mazzarol et al dalam Saud et .al. (2009) menemukan bahwa faktor demografi pengalaman kerja, usia, jender, status sosio-ekonomi, agama mempengaruhi minat mendirikan usaha.

Tabel 5. Hasil Uji Parsial (Uji-t)

\begin{tabular}{llll}
\hline \multicolumn{1}{c}{ Model } & T & Sig. \\
\hline 1 & (Constant) & .508 & .613 \\
Kebutuhan Prestasi & .960 & .340 \\
Efikasi Diri & 1.321 & .190 \\
Ketersediaan Informasi & 1.863 & .066 \\
Jaringan & .917 & .362 \\
Akses Modal & .843 & .402 \\
& Demografi & 2.737 & .007 \\
\hline
\end{tabular}

Sumber: Hasil Pengolahan Data

Dari hasil uji-t terhadap Demografi diketahui bahwa thitung sebesar 2,737 sedangkan tabel dengan tingkat kepercayaan $95 \%$ atau $\alpha=0,05$ sebesar 1,98 sehingga dengan demikian thitung $>$ tabel, Hal ini berarti bahwa variabel demografi berpengaruh signifikan terhadap minat kewirausahaan pemuda di kecamatan Percut Sei Tuan.

Berdasarkan hasil Uji-t disimpulkan bahwa efikasi diri, kebutuhan prestasi, ketersediaan informasi, kepemilikan jaringan, dan akses modal tidak berpengaruh signifikan terhadap variabel minat kewirausahaan pemuda di Kecamatan Percut Sei Tuan Kabupaten Deli Serdang. Sementara, demografi berpengaruh signifikan terhadap variabel minat kewirausahaan pemuda di Kecamatan Percut Sei Tuan Kabupaten Deli Serdang.

Kebutuhan akan prestasi memiliki hubungan positif dan tidak berpengaruh signifikan terhadap minat kewirausahaan pemuda di kecamatan Percut Sei Tuan. Hasil tersebut sesuai dengan Penelitian Indarti et al yang menemukan bahwa variabel kebutuhan akan prestasi tidak 
mempunyai pengaruh yang positif terhadap minat kewirausahaan mahasiswa Indonesia dan Norwegia, sebaliknya pada penelitian Setiyorini (2009) ditemukan bahwa motivasi berprestasi pada mahasiswa Universitas Sebelas Maret Surakarta mempunyai pengaruh yang positif terhadap minat kewirausahaan mahasiswa. Berprestasi tidak hanya dapat dicapai dengan berwirausaha, namun juga dengan bekerja pada karir tertentu. Misalnya dalam penelitian ini, objek penelitian tidak hanya mahasiswa (seperti kebanyakan penelitian dengan tema sama), melainkan juga pemuda yang berprofesi sebagai guru, karyawan, pegawai dan pengagguran. Kepribadian yang butuh terhadap prestasi adalah orang-orang yang memiliki motivasi untuk mengaktualisasikan dirinya. Kebutuhan akan prestasi merujuk pada keinginan seseorang terhadap prestasi yang tinggi, penguasaan keahlian, pengendalian atau standar yang tinggi pada bidang yang sedang digelutinya.

Efikasi diri memiliki hubungan positif dan tidak berpengaruh signifikan terhadap minat kewirausahaan pemuda di kecamatan Percut Sei Tuan. Hal ini berbeda dengan hasil penelitian Betz dan Hacket (1986) dalam Indarti dan Rotiani (2008) yang mengatakan bahwa semakin tinggi tingkat efikasi diri seseorang pada kewirausahaan di masa-masa awal seseorang dalam berkarir, semakin kuat intensi kewirausahaan yang dimilikinya. Wijaya (2007) menyatakan bahwa efikasi diri mempengaruhi seseorang pada tercapai atau tidaknya tujuan yang ditetapkan. Responden penelitian ini terdiri atas para pemuda yang 31 orang diantaranya sudah berprofesi baik sebagai guru, karyawan swasta, dan pegawai negeri sipil. Keyakinan pada diri mereka tumbuh untuk tujuan sesuai profesi mereka. Selain itu, responden yang terdiri dari mahasiswa dan pelajar berjumlah 39 orang. Orientasi pendidikan menghasilkan lulusan untuk bekerja pada perusahaan bukan untuk menjadi wirausaha. Hingga efikasi diri pada mahasiswa dan pelajar tersebut tidak memberikan pengaruh signifikan terhadap minat wirausaha.

Faktor ketersediaan informasi memiliki hubungan positif dan tidak berpengaruh signifikan terhadap keinginan berwirausaha. Hasil penelitian berbeda dengan hasil penelitian Diana (2010) yang menyatakan ketersediaan informasi mempengaruhi keinginan berwirausaha para pengusaha grosir di jalan Bandung. Sebaliknya, hasil penelitian ini sesuai dengan penelitian yang dilakukan oleh Ali Sutanto (2005) yang 
menyatakan bahwa tidak ada pengaruh signifikan antara ketersediaan informasi terhadap keinginan berwirausaha. Meskipun demikian, jika taraf signifikansi sama dengan pengambilan sampel yaitu 0,10, maka factor ketersediaan informasi juga berpengaruh signifikan terhadap minat wirausaha.

Hasil penelitian menunjukan kepemilikan jaringan memiliki hubungan positif dan tidak berpengaruh signifikan terhadap minat berwirausaha pemuda di kecamatan Percut Sei Tuan. Hasil ini sesuai dengan penelitian Ani Murwani (2013) yang menyimpulkan bahwa kesiapan instrument (akses modal, jaringan, dan informasi) tidak berpengaruh signifikan terhadap minat kewirausahaan mahasiswa Universitas Negeri Medan (Unimed). Selanjutnya penelitian Hermin (2013) yang menyimpulkan bahwa kesiapan instrument (akses modal, jaringan, dan informasi) tidak berpengaruh signifikan terhadap minat kewirausahaan di Universitas Muhammadiyah Ponorogo dan Universitas Soedirman. Dalam penelitian ini, jaringan yang dimiliki responden bukanlah jaringan yang mendorong untuk berwirausaha, misalnya organisasi structural, keagamaan, dan lingkungan. pergaulan luas yang dimiliki responden, terbatas hanya untuk hiburan dan bekerja.

Akses modal memiliki hubungan positif dan tidak berpengaruh signifikan terhadap minat wirausaha pemuda. Hasil penelitian menunjukkan bahwa variabel akses modal memiliki nilai skor rata-rata 3,03. Hal ini berarti bahwa akses modal pemuda di kecamatan percut sei tuan berada pada daerah netral. Hasil penelitian ini sesuai dengan teori yang diungkapkan Suryana (2010:5) dalam kewirausahaan, modal tidak selalu identik dengan modal yang berwujud (tangible) seperti uang dan barang, tetapi juga modal yang tidak berwujud (intangible) seperti modal intelektual, modal sosial, modal moral dan modal mental yang dilandasi agama. Lebih lanjut, hasil penelitian ini sesuai dengan hasil penelitian Yuliawan (2015) bahwa akses modal tidak berpengaruh signifikan terhadap minat wirausaha mahasiswa Mikroskill.

Minat wirausaha pemuda di kecamatan Percut Sei Tuan tumbuh, meskipun dengan keterbatasan akses modal. Meskipun demikian, ketersediaan akses modal tidak bisa dianggap sebagai factor yang patut diabaikan dalam memulai wirausaha. Minat dalam penelitian ini lebih pada ketertarikan seseorang untuk melakukan wirausaha. Oleh sebab itu,

QE Journal | Vol.06 - No. 01 Maret 2017 - 64 
tersedianya akses modal tentu akan mempermudah terealisasinya wirausaha terlebih bagi para pemuda yang memiliki minat wirausaha. Hal ini sesuai dengan hasil analisis regresi yang menunjukkan adanya hubungan positif antara akses modal dan minat wirausaha.

Hasil penelitian menunjukkan bahwa demografi; pendidikan, pengetahuan, dan pengalaman memiliki hubungan positif dan berpengaruh signifikan terhadap minat wirausaha pemuda di kecamatan precut Sei Tuan.. Hasil penelitian ini sesuai yang dilakukan oleh Nisa (2015) bahwa faktor pendidikan adalah salah satu faktor yang memengaruhi minat usaha di Pasar Petisah, Medan. Hasil penelitian Melviana (2016) juga menunjukkan hal yang sama yaitu pendidikan berpengaruh positif dan signifikan terhadap minat memulai usaha di sekitar Swalayan Super Tasbih Medan. Agar wirausaha menjadi efektif, seseorang harus banyak belajar melalui pendidikan maupun pengalaman. Karena pendidikan akan melahirkan pengetahuan, dan pengalaman akan melahirkan pengajaran.

Pemerintah Kabupaten Deli Serdang telah mencanangkan program kewirausahan bagi para pemuda dalam Rencana Pembangunan Jangka Menengah Daerah. Tentunya hal ini, tidak hanya menjadi tanggung jawab Pemerintah saja, namun menjadi tanggung jawab khususnya para pemuda. Dalam penelitian ini, telah dibuktikan bahwa minat wirausaha tidak hanya dipengaruhi oleh factor lingkungan; ketersediaan informasi, kepemilikan jaringan, dan akses modal, melainkan juga factor internal baik itu kepribadian; efikasi diri dan kebutuhan akan prestasi, dan modal manusia atau demografi; pengalaman dan pengetahuan. Dengan demikian dalam menunjang keberhasilan program kewirausahaan pemuda, Pemerintah dan Pemuda harus bersinergi dalam mewujudkannya. Para pemuda harus membenahi kepribadian, pengetahuan, dan pengalamannya sedangkan femerintah harus memfasilitasi dengan membuka akses informasi wirausaha, menyediakan modal wirausaha, memberikan pendampingan dan pendidikan kewirausahaan.

\section{SIMPULAN DAN SARAN}

\section{Simpulan}

Berdasarkan hasil penelitian dan pembahasan maka, dapat ditarik kesimpulan sebagai berikut: 
1. Minat wirausaha pemuda di Kecamatan Percut Sei Tuan Kabupaten Deli Serdang berada pada daerah sangat positif.

2. Minat wirausaha pemuda di Kecamatan Percut Sei Tuan ditinjau dari karakteristik responden sebagai berikut:

a. Minat wirausaha pemuda laki-laki lebih tinggi dibandingkan minat wirausaha pemuda perempuan.

b. Minat wirausaha pemuda suku Jawa lebih tinggi dibandingkan minat wirausaha pemuda suku Melayu dan Batak secara berturut.

c. Minat wirausaha pemuda tingkat pendidikan SMA lebih tinggi dibandingkan minat wirausaha pemuda tingkat pendidikan S-1.

d. Minat wirausaha pemuda yang bekerja sebagai wirausaha lebih tinggi dibadingkan minat wirausaha pemuda mahasiswa dan guru secara berturut.

e. Minat wirausaha pemuda yang berpenghasilan besar lebih tinggi dibandingkan minat wirausaha pemuda berpenghasilan kecil.

f. Minat wirausaha pemuda yang memiliki jumlah tanggungan lebih tinggi dibandingkan minat wirausaha pemuda yang belum memiliki tanggungan.

3. Hubungan dan pengaruh antara Efikasi Diri, Kebutuhan Prestasi, Ketersediaan Informasi, Jaringan, Akses Modal, dan Demografi terhadap minat wirausaha pemuda di Kecamatan Percut Sei Tuan sebagai berikut:

a. Efikasi Diri, Kebutuhan Prestasi, Ketersediaan Informasi, Jaringan, Akses Modal, dan Demografi memiliki hubungan positif terhadap variabel minat kewirausahaan pemuda di Kecamatan Percut Sei Tuan Kabupaten Deli Serdang.

b. Efikasi Diri, Kebutuhan Prestasi, Ketersediaan Informasi, Jaringan, Akses Modal, dan Demografi secara simultan berpengaruh signifikan terhadap variabel minat kewirausahaan pemuda di Kecamatan Percut Sei Tuan Kabupaten Deli Serdang.

c. Efikasi Diri, Kebutuhan Prestasi, Ketersediaan Informasi, Jaringan, dan akses modal secara parsial tidak berpengaruh signifikan 
terhadap variabel minat kewirausahaan pemuda di Kecamatan Percut Sei Tuan Kabupaten Deli Serdang.

d. Demografi secara parsial berpengaruh signifikan terhadap variabel minat kewirausahaan pemuda di Kecamatan Percut Sei Tuan Kabupaten Deli Serdang.

\section{Saran}

Adapun saran berdasarkan hasil penelitian ini sebagai berikut:

1. Variabel Efikasi Diri, Kebutuhan Prestasi, Ketersediaan Informasi, Jaringan, Akses Modal, dan Demografi memiliki hubungan positif dalam menumbuhkan minat kewirausahaan pemuda. Dalam rangka mewujudkan Rencana Pembangunan Jangka Panjang dan Menengah, Pemerintah Daerah Deli Serdang disarankan membuat kebijakan, yang mampu menumbuhkan kepribadian dan lingkungan berwirausaha, seperti pemberian modal, transparansi informasi wirausaha, dan workshop kewirausahaan.

2. Demografi secara parsial berpengaruh signifikan terhadap variabel minat kewirausahaan pemuda di Kecamatan Percut Sei Tuan Kabupaten Deli Serdang. Oleh sebab itu pendampingan secara intensif kepada wirausaha pemuda yang dilahirkan melalui program-program pemerintah harus dilakukan untuk meningkatkan pengalaman berwirausaha.

3. Sebagian besar faktor yang menjadi determinan Minat wirausaha pemuda adalah Efikasi Diri, Kebutuhan Prestasi, Ketersediaan Informasi, Jaringan, Akses Modal, dan Demografi. Oleh sebab itu, para pemuda harus membenahi kepribadian dan lingkungannya agar dapat mendukung terbentuknya minat wirausaha.

4. Minat wirausaha dipengaruhi oleh variabel lain di luar penelitian ini, oleh sebab itu disarankan agar peneliti selanjutnya mendalami faktorfaktor lain yang mempengaruhi minat wirausaha.

\section{DAFTAR PUSTAKA}

Arikunto, Suharsimi. 2002. Prosedur Penelitian, Suatu Pendekatan Praktek. Rineka Cipta. Jakarta

QE Journal | Vol.06 - No. 01 Maret 2017 - 67 
Badan Pusat Statistik. 2015. Percut Sei Tuan dalam Angka 2015. Katalog BPS, Deli Serdang

Badan Pusat Statistik. 2015. Statistik Daerah Provinsi Sumatera Utara 2015. Katalog BPS, Medan

Bambang, Siswoyo. 2009. Pengembangan Jiwa Kewirausahaan di Kalangan Dosen dan Mahasiswa. Jurnal Ekonomi Bisnis: No. 2. Bandung

Bandura, A. 2006. Guide for Constructing Self-Efficacy Scale. Age Publishing, Greenwich

Benedicta Prihatin Dwi, Riyanti. 2003. Kewirausahaan Dari Sudut Pandang. Psikologi Kepribadian. Grasindo, Jakarta.

Betz, N. E. dan Hackett. 2006. Self-Efficacy Theor: Back to The Future. Journal of Career Assesment Vol. 14 No. 1

Ciputra. 2008. Bagaimana Entrepreneurship Dapat Mengubah Masa Depan Anda dan Masa Depan Bangsa. PT. Gramedia, Jakarta.

Danang Sunyoto. 2009. Analisis Regresi dan Uji Hipotesis. MedPress. Yogyakarta 2009.

Direktoret Jenderal Kependudukan dan Catatan Sipil, Kementerian Dalam Negeri Republik Indonesia. 2017. Statistik Jumlah Kependudukan. Jakarta

Drabenstott, M. 2006. Rethinking federal policy for regilonal economic development. Economic Review, first quarter: 115-142

Endratno, Hermin, dkk. 2013. Intensi Kewirausahaan Mahasiswa (Studi Banding antara Mahasiswa FE UMP dan FE UNSOED). Journal Sustainable Competitive Advantage FEB Unsoed Vol. 4, No. 1

Indarti. 2008. Intensi Kewirausahaan Mahasiswa: Studi Perbandingan antara Indonesia, Jepang, dan Norwegia. Universitas Gadjah Mada, Yogyakarta

Kristiansen, S, 2002. Individual perception of business contexts: the case of smallscale entrepreneurs in Tanzania. Journal of Developmental Entrepreneurship 7 (3). 
Kristiansen, S., B. dkk, 2003. Internet cafe entrepreneurs: pioneers in information dissemination in Indonesia. The International Journal of Entrepreneurship and Innovation 4 (4): 251-263.

Limbong, Benri. 2010. Pengaruh antara Sikap Mandiri, Pengetahuan Kewirausahaan dan Motivasi Berwirausaha terhadap Minat Berwirausaha Siswa-siswi SMK di Kota Medan. Tesis. Universitas Sumatera Utara, Medan.

Longenecker, Justin. G. etc. 2001. Kewirausahaan Manajemen Usaha Kecil. PT. Salemba Empat, Jakarta

Mc. Clleland, D (1961). The achieving Society. Princeton.NewJersey: Sostrand

Miraza, Bachtiar Haassan. 2008. Mencermati Perilaku Entrepreneur. Penerbit USU Press, Medan

Mopangga, Herwin. 2014. Faktor Determinan Minat Wirausaha Mahasiswa Fakultas Ekonomi dan Bisnis Universitas Negeri Gorontalo. Jurnal Trikonomika: Volume 13. Gorontalo

Murwani, Ani. 2013. Analisis faktor-faktor yang mempengaruhi minat berwirausaha mahasiswa (studi kasus pada stmik mikroskil medan). Jurnal Keuangan dan Bisnis, Volume 5 No. 1

Nugroho, Iwan, dkk. 2004. Pembangunan Wilayah: Persepektif ekonomi, social dan lingkungan. Penerbit Pustaka LP3ES. Jakarta.

Nugroho, Iwan. 2008. Implementasi Pembangunan Wilayah: Menuju Pertumbuhan Ekonomi Berkelanjutan. Universitas Widyagama. Malang

Nurgiyantoro, Burhan, etc. 2000. Statistika Terapan: Penelitian dalam Ilmuilmu Sosial. Gadjah Mada University Press. Yogyakarta.

Pemerintah Kabupaten Deli Serdang. 2014. Rencana Pembangunan Jangka Menengah Daerah Tahun 2014-2019. Lubuk Pakam

Riyanti B.P.D. 2003. Kewirausahaan dari Sudut Pandang Psikologi Kepribadian. Grasindo, Jakarta 
Suhartini, Yati. 2011. Analisis Faktor-faktor yang Mempengaruhi Minat Mahasiswa dalam Berwiraswasta. Jurnal Ekonomi: Volume 7. Yogyakarta.

Suryana. 2001. Kewirausahaan. Salemba Empat, Jakarta.

Susanto, Ali (2005). Hubungan karakteristik dan Kewirausaah dan Dengan Keberhasilan Bertahan (Studi Kasus pada Koperasi).Jurnal Ekonomi, 1

Winardi. 2003. Entrepreneur dan Entrepreneurship. Kencana Prenada, Jakarta.

Yuliawan, Eko. 2015. Analisis Faktor-Faktor Yang Mempengaruhi Minat Berwirausaha Mahasiswa (Studi Kasus Pada Stmik Mikroskil Medan). Jurnal Wira Ekonomi Mikroskill Vol.5 No. 1. 